\title{
Determinants of Trade Balance in Vietnam During 1997-2015
}

\author{
Trung-Thanh To* \\ Department of Economics, National Economics University, Vietnam \\ thanhtt@neu.edu.vn* \\ * corresponding author
}

\begin{abstract}
This paper investigates the determinants of trade balance in Vietnam during 1997-2015, based on the restricted VECM model. The result suggests that in the long run, the openness has negative impact on trade balance. The initial level of NFA is negatively associated with trade balance. The more developed financial system can improve trade balance meanwhile higher income can worsen it. REER could have no close relationship with trade balance. Increasing FDI can contribute to trade deficit meanwhile capital mobility could improve trade balance. The trade balance also has a self-adjusting mechanism towards long-run equilibrium after the shocks to explanatory variables.
\end{abstract}

Keywords: Trade balance, VECM, REER, FDI, NFA

\section{Introduction}

Ever since the fundamental changes from the reform in 1986, the international trade in Vietnam has been making remarkable progress, contributing to the rapid economic growth in the last 30 years. However, trade deficit has become a major trend since 2000. If the average trade deficit was at $9.1 \%$ of GDP during 2001-2005, during the next 5-year period, the level of deficit raised to 14.7\% GDP. During 2011-2014, trade deficit appeared signs of decline along with the economic recession [1]. However, trade balance deteriorated again in 2015 when the economy started recovering. It could be said that trade balance has fluctuated greatly and been unstable, affecting unfavorably the economic development in Vietnam. There have been several studies seeking the determinants of trade deficit in Vietnam. However, they showed some fundamental limitations, including not employing latest approaches to trade balance such as the intertemporal approach, lack of adopting modern quantitative models such as VECM, not simultaneously covering many determinants of trade balance due to deficiency in supporting theories. This study will attempt to overcome those limitations [2].

The objective of the study is to investigate the main causes explaining trade deficit in Vietnam, and from that, propose policy recommendations to achieve sustainable trade balance [3]. Given the data availability, the scope of the study is from 1997-2015, which is also a period when Vietnam integrated extensively into the global economy, and experienced greatly volatile trade balance. We will employ the restricted Vector Error Correction Model (VECM) with the variables selected on the basis of a theoretical framework, which is developed from integrating several different approaches to trade balance in order to capture various main causes that led to the trade deficit in Vietnam. The study will make use of quarterly data, collecting from various Vietnamese and international sources including Vietnam General Statistics (GSO), State Bank of Vietnam (SBV), International Monetary Fund (IMF) and World Bank (WB). The study will start with a brief literature, and next comes the theoretical and empirical framework. The estimation results and the discussions will be the next part and then followed by the conclusion and policy implications. 


\section{Literature Review}

There are a variety of different approaches to balance of trade. The elasticity approach supports the viewpoint that the nominal exchange rate is the main determinant of trade balance. This approach proposes the Marshall-Lerner condition, accordingly, the devaluation of domestic currency will improve trade balance only if the sum of the elasticities of exports and imports to exchange rate is greater than 1. It should be noted that this condition only ensures the improvement of trade balance at the new equilibrium, it does not guarantee better or worse trade balance during the adjustment process to the new equilibrium [4].

The J-curve effect is also proposed in this approach to denote the time path of the trade balance, which is initially deteriorated and subsequently improved to a level higher than the level prior to the devaluation. The multiplier approach applies to small open economies. This is the so-called multiplier without foreign repercussions, which implies that exports are considered as the exogenous variable [5-6]. It is supposed that the balance of trade moves from the equilibrium due to an increase in exports, leading to a trade surplus. The rise of exports will increase disposable income, then increase imports given the marginal propensity to imports. The increase in imports will compensate for the initial increase in exports. Whether or not the trade balance will adjust to the equilibrium depends on the relative magnitude of the increase in imports to the initial increase in exports [7].

The monetary approach suggests that trade balance is essentially a monetary phenomenon, the trade imbalances reflect stock disequilibria in the money market. Accordingly, if the economy has an excess supply of money, it will address it by raising absorption (excess absorption with respect to national income) and then passing this excess to foreign economies for the goods and services, which implies trade deficit. On the other hand, if the economy has excess money demand, it will get rid of it by decreasing absorption and then passing goods and services to foreign economies for money, which implies trade surplus.

The absorption approach evaluates not only the price effect like the elasticity approach, but also the income effect of the devaluation. The starting point of this approach is the accounting identity that trade balance is the national income less absorption, or national saving less investment. According to this approach, the effects of devaluation include effects via income, consisting of idle-resources effect, terms-of-trade effect; and direct effects on absorption, consisting of cash-balance effect, income-redistribution effect, money-illusion effect, and others. A devaluation will improve the trade balance if it creates a suitable combination of changes in income and absorption, for example, the former increases by more than the latter.

The inter-temporal approach is subject to the forward-looking behaviour, which is one of the hallmarks of modern macroeconomics. This modern approach could be regarded as an extension of the absorption approach, because it is also based on the same viewpoint, but with another assumption that private saving and investment decisions are forward looking. The intertemporal approach also takes into account the relative price as the decisive factor of saving and investment, therefore, this approach could be seen as the modern synthesis of the elasticity and the absorption approaches. This approach shows that the dynamics of the current account (or the trade balance) reflects the factors that affects the economy's consumption, saving and investment across periods.

Each of the above-mentioned approaches attempts to explain the dynamics of trade balance with a variety of explanatory variables, but they have some limitations [8]. The elasticity approach mainly investigates the short-run impacts of devaluation on trade balance because of their partial equilibrium's perspective. The monetary approach depends on a very strict assumption that expenditure is a result of the adjustment of money supply and demand. The multiplier and absorption approaches ignore the price effect of devaluation [9]. The inter-temporal approach does not yet reach a consensus on the assumption of economic agents' preferences. On the other hands, some factors behind the trade balance dynamics are not controversial across approaches [10]. The determinants of trade balance have been then mostly investigated through empirical findings. The empirical studies on trade balance have more focused on the developed countries before 1997 due to lack of data availability in developing countries in general and in Vietnam in particular [11]. 
However, after the Asian crisis, the literature has started to pay attention to the developing and emerging countries. These studies have applied different approaches, different estimation methods and different findings. Using data of 21 industrial countries in the period of 1971-1993 and additional 34 industrial and developing countries, show that relative income, demographic factors and government debt are long-run determinants of current account and the real exchange rate, terms of trade are the short-run factors explaining the fluctuation of current account [12]. By studying 44 developing countries over the period of 1966-1995 with more advanced econometric methods to control for joint endogeneity and differentiate cross and within-country effects, find that those countries whose own a high level of debt could face a low stability of the current account deficit. In addition, the increase in exports would improve the trade balance and reduce the current account deficit of a country, while the differences between countries in terms of export scale are associated with the differences in the current account deficit.

Adopting cross-section and panel regression techniques to study a sample of 18 industrialized countries and 71 developing countries over the period of 1971-1995, find that there is a positive correlation between trade balance and budget balance and net foreign asset (NFA). Gruber and Kamin [13] test the hypothesis that the model of global current account and trade balance imbalance can be explained by the disparity of the financial development. The experimental results for 84 countries over the period of 1982-2006 suggest a little evidence to support this hypothesis. Rahman [14] examines trade deficit of the new members of the European Union (EU) by adding three new regression variables, including foreign direct investment (FDI), remittances and a conversion index representing the investment environment, to the list of common variables such as business cycles and exchange rates.

His research shows that FDI and the conversion index have considerable and negative influence on trade balance while remittances has positive effect on trade balance. Christiansen et al. [15] focus on extra factors under the condition of low-income countries, such as institutional quality, the official external financing and the role of economic shocks. Their study indicates that the domestic financial liberalization could improve trade balance, while the capital account liberalization has an opposite effect. The work of Jang [16] on the factors affecting the current account balance and trade balance of emerging Asian countries shows that the impacts of several variables of NFA, trade open and real effective exchange rate (REER) on balance trade are very different across countries.

In Vietnam, Tu and Dao (2008), by using the gravity model to assess trade between Vietnam and Association of Southest Asian Nation (ASEAN) + 3 (Japan, Korea and China), indicate that the critical determinant of trade deicit is the targeted economic growth. Narray et al. [15,19] analyze the relationship between the trade deficit of Vietnam and WTO, accordingly, the main cause for the trade deficit in Vietnam is a huge volume of imported raw materials and inputs for production and export. The rise in trade deficit is also derived from a rapid cut of the protection barriers since Vietnam integrated to ASEAN, joined free trade areas of ASEAN, ASEAN-China, ASEAN-India, ASEAN-Korea and negotiated to become an official member of WTO in 2007. The reseach of Nguyen et al. [16] based on the cross-industry input/output (I/O) method, finds that the direct and indirect determinanst of trade deficit in Vietnam from 2000 to 2009 are not the final consumpton demand but the weaknesses and inefficiency in manufacturing industries. These manufacturing industries have been pramperd by the government's policy over a long period and mostly engaged in either outsourcing activities with foreign companies or manufacturing with the majority of imported inputs and machines.

Applying similar I/O method, To et al. [17] find the spillover effect of exports to value added is lowest, but the exports induced impact on imports is very high, which explain why trade deficit in Vietnam could not be addressed by the currency devaluation. Nguyen [18] points out that the devaluation of VND could not nescessarily strengthens the competitiveness of exports. Besides, the capacity to produce goods replacing imports and quality of exports from Vietnam remain limited. Nguyen [19], therefore, suggests that managing exchange rate to boost export and control import should be an medium-term issue. In brief, the literature of trade balance shows different results across countries. Meanwhile, among related studies in Vietnam, there are some visible shortcomings, including: i) not applying some latest approaches such as the intertemporal approach; ii) lack of effective quantitative methods like 
VECM, and iii) not covering all the causes of trade balance from different approaches. Those limitations will be filled up in this study.

\section{Theoretical issues and empirical framework}

\subsection{Theoretical issues}

Because of the fact that no single theoretical approach can capture all possible determinants of trade balance, we will investigate main variables that can have possible impacts on trade balance from different approaches. Due to lack of data availability in Vietnam for the empirical study, we will select only some following explanatory variables to predict the impacts on trade balance, which will be then tested in the empirical study.

\subsection{The trade openness}

Trade openness measures the degree of an economy's openness to the global economy, reflecting some of the macroeconomic policies and trade restrictions, related to the development of long-run external balance. Greater level of trade openness will contribute to the expansion of exports and facilitate import activities [20]. Domestic products will have more opportunities to be exported in greater volumes and penetrate more easily into the global markets, meanwhile the domestic markets will have more access to foreign goods, services and technology. Because this variable could have positive impacts on both imports and exports, its total effect on trade balance is ambiguous.

\subsection{The initial stock of NFA}

According to the intertemporal approach, the initial position of NFA can affect current account and balance. The sum of the current account and capital account is zero in a flexible exchange rate regime, implying that an economy with a larger stock of NFA can afford a current account and trade deficit during an extended period and remain solvent. This could lead to a negative relationship between this variable and the trade balance. However, an economy with a higher level of NFA could achieve higher investment income from abroad, which could have positive impact on the saving-investment perspective, then improving trade balance.

\subsection{The financial depth}

According to the monetary approach, the surplus in the money market could result in trade deficit. The economy will have higher absorption than income, which means higher consumption of foreign goods and services. However, according to the intertemporal approach, the financial depth, which could measure the development of financial system, is one determinant of savings. A more developed financial system will result in higher saving ratio, leading to a trade balance improvement.

\subsection{The relative income}

The multiplier and the absorption approach imply that when income is higher, expenditure will increase, then deteriorating trade balance. However, according to the intertemporal approach, this variable reflects the stage of development. At an early development stage, an economy could have negative current account balance to import capital for external financing requirement. At the higher stages of development, the economy will maintain trade surplus to pay back the previously accumulated external liabilities, and export capital to the less developed countries.

\subsection{The exchange rate}

According to the elasticity approach, the nominal devaluation of the domestic currency might improve trade balance in the long run if the Marshall-Lerner condition is satisfied. Meanwhile, the intertemporal approach indicates that an appreciation of real exchange rate will increase the purchasing power of the domestic currency on foreign goods and services, thereby increasing real consumption relative to income, then decreasing the propensity to save, which can deteriorate trade balance. 


\subsection{Foreign direct investment}

The impact of FDI on trade balance could be ambiguous. On one hand, increased FDI would be a stable source to finance the trade deficit. Moreover, the impact of FDI on the trade balance is also through increasing economic growth and higher NFA accumulation, which could increase trade deficit. Higher FDI could also lead to increased imports, deteriorating trade balance. On the other hand, FDI could be an important source to improve the domestic production capability as well as the national export capability, contributing to improvement in trade balance.

\subsection{The capital mobility degree}

According to the intertemporal approach, an economy with more capital mobility is likely to attract more foreign capital to finance absorption relative to income. This implies that economies that maintain a relatively open capital account will tend to have larger trade deficit. However, the control of capital account could be considered as a negative sign indicating that one economy is facing difficulties in managing the external balance, it has to employ the capital count control to counter the capital outflows in concern of current account imbalance in the past.

\section{Methodology}

Guided by the above-mentioned theoretical issues and due to data availability, we will examine the impacts of trade openness, NFA, financial depth, relative income, REER, FDI and capital mobility degree on trade balance in Vietnam [21]. The study will use quarterly data from 1997Q1 to 2005Q4. The notation, measurement and source of all variables are presented in Table 1. In order to examine the long-run relationship between the explanatory variables and the trade balance as well as the short-run dynamics of trade balance in response to different shocks to endogenous variables, we will adopt the VECM model for the empirical study.

This is a powerful model for the above objectives, then contributing to deeper and more comprehensive analysis of trade balance in Vietnam. We will investigate the long-run relationship (through the cointegration equation), the speed of adjustment of trade balance to its long-run equilibrium (through estimated coefficient of the error correction term), the short-run impact of shocks to explanatory variables on trade balance (through impulse response functions and variance decompositions).

Table. 1. Variables used in the estimation model

\begin{tabular}{llll}
\hline Variables & Notation & Measurement & Data source \\
\hline Trade balance & TB1 & $\begin{array}{l}\text { (trade balance/GDP)*100\% } \\
\text { The higher this variable is, the more } \\
\text { improved trade balance is }\end{array}$ & $\begin{array}{l}\text { Financial Statistics } \\
\text { (IFS), IMF; General } \\
\text { Statistics Office } \\
\text { (GSO) }\end{array}$ \\
\hline $\begin{array}{l}\text { Trade } \\
\text { openness }\end{array}$ & LNOPEN & $\begin{array}{l}\text { Ln[(EX+IM)/GDP)*100\%] } \\
\text { The higher this variable is, the more open } \\
\text { the economy is }\end{array}$ IFS, GSO \\
\hline $\begin{array}{l}\text { Net foreign } \\
\text { assets }\end{array}$ & LNNFA_GDP & $\begin{array}{l}\text { Lne initial NFA is computed with one- } \\
\text { period lag to avoid the endogeneity IFS, GSO } \\
\text { problem. } \\
\text { The higher this variable is, the more the } \\
\text { NFA stock is }\end{array}$ \\
\hline
\end{tabular}




\begin{tabular}{|c|c|c|c|}
\hline $\begin{array}{l}\text { Financial } \\
\text { depth }\end{array}$ & LNM2_GDP & $\begin{array}{l}\operatorname{Ln}\left[(\mathrm{M} 2 / \mathrm{GDP})^{*} 100 \%\right] \\
\text { The higher this variable is, the deeper the } \\
\text { financial system is }\end{array}$ & IFS, GSO \\
\hline $\begin{array}{l}\text { Relative } \\
\text { income }\end{array}$ & LNREL_Y2 & $\begin{array}{l}\text { Ln[(GDP per capita of Vietnam/GDP per } \\
\text { capita of USA)*100\%] } \\
\text { GDP per capita is computed at the constant } \\
1997 \text { price. } \\
\text { The higher this variable is, the higher the } \\
\text { domestic relative income is }\end{array}$ & IFS, GSO \\
\hline $\begin{array}{l}\text { Real effective } \\
\text { exchange rate }\end{array}$ & LNREER & $\begin{array}{l}\text { Ln(REER) } \\
\text { This reflects the value of foreign } \\
\text { currencies in terms of Vietnamese dong } \\
\text { (VND). The base year for calculating } \\
\text { REER is Q1 1997. Top trading partners } \\
\text { with Vietnam include China, the US, } \\
\text { Thailand, Korea, Japan, Singapore, India, } \\
\text { the UK, Malaysia, Germany, France, } \\
\text { Canada and Australia. } \\
\text { The higher this variable is, the more } \\
\text { depreciated the VND is }\end{array}$ & $\begin{array}{l}\text { Direction of Trade } \\
\text { Statistics (DOTS), } \\
\text { IFS, State Bank of } \\
\text { Vietnam }\end{array}$ \\
\hline $\begin{array}{l}\text { Foreign direct } \\
\text { investment }\end{array}$ & LNFDI_GDP & $\begin{array}{l}\operatorname{Ln}[(\mathrm{FDI} / \mathrm{GDP}) * 100 \%] \\
\text { The more this variable is, the more } \\
\text { attracted the economy is to foreign } \\
\text { investors. }\end{array}$ & IFS, GSO \\
\hline $\begin{array}{l}\text { Capital } \\
\text { mobility } \\
\text { degree }\end{array}$ & LNTF_GDP & $\begin{array}{l}\operatorname{Ln}\left[(\mathrm{FA}+\mathrm{FL} / \mathrm{GDP})^{*} 100 \%\right] \\
\text { Where FA and FL are foreign assets and } \\
\text { foreign liabilities. FA and FL include } \\
\text { assets and liabilities in accounts of FDI, } \\
\text { portfolio investment, financial assets... } \\
\text { The higher this variable is, the less } \\
\text { controlled the capital account is }\end{array}$ & IFS \\
\hline
\end{tabular}

\section{Estimation result and discussion}

\subsection{Estimation result}

The results of ADF unit root tests shown in Table 2 indicate that all variables are integrated of order 1, i.e. I(1). To test for cointegration relation in the model, we need to identify the optimal lag length. Most of criteria including Likelihood Ratio test (LR), Akaike Information Criterion (AIC), Schwarz Information Criterion (SIC) suggest that the optimal lag length for VAR model is 3, the Johansen cointegration test and VECM model are then estimated at the lag of 2. The Johansen cointegration test result shows that there is one cointegration relationship existing between the trade balance and the explanatory variables (see Table 3). Therefore, the selected variables meet all requirements for estimating a VECM model.

Table. 2. ADF unit root tests

\begin{tabular}{llll}
\hline \multirow{3}{*}{ Variables } & \multicolumn{1}{l}{ Levels } & First difference \\
\cline { 2 - 4 } & (t-statistic) & (t-statistic) & \\
\cline { 2 - 4 } & Without trend & With trend & $\begin{array}{l}\text { Without } \\
\text { trend }\end{array}$
\end{tabular}




\begin{tabular}{lllll}
\hline TB1 & -2.353 & -2.509 & $-8.593^{* * *}$ & $-8.652^{* * *}$ \\
\hline LNOPEN & -1.016 & -2.105 & $-11.152^{* * *}$ & $-11.075^{* * *}$ \\
\hline LNNFA_GDP & $-2.607^{*}$ & -2.356 & $-3.089^{* *}$ & $-3.264^{* * *}$ \\
\hline LNM2_GDP & -1.980 & -1.319 & $-4.966^{* * *}$ & $-5.276^{* * *}$ \\
\hline LNREL_Y2 & -0.680 & -2.593 & $-18.264^{* * *}$ & $-18.287^{* * *}$ \\
\hline LNREER & -0.551 & -2.035 & $-8.382^{* * *}$ & $-7.302^{* * *}$ \\
\hline LNFDI_GDP & -1.786 & -2.069 & $-8.926^{* * *}$ & $-8.959^{* * *}$ \\
\hline LNTF_GDP & -2.019 & -1.734 & $-4.106^{* * *}$ & $-4.224^{* * *}$ \\
\hline
\end{tabular}

Note: $* * *$ and $* * *$ : statistically significant at $10 \%, 5 \%$ and $1 \%$, respectively. The optimal lag length is selected by $\mathrm{SIC}$

The VECM model is then estimated with 2 lags and 1 co-integration relationship. Further analysis on the short-run dynamics of trade balance is implemented by testing the hypothesis of weak exogeneity for variables. It is carried out by imposing zero restriction on the adjustment coefficients $\alpha$. The test results indicate that the variables including LNNFA_GDP, LNM2_GDP, LNREL_Y2, LNREER and LNTF_GDP show weak exogeneity. Therefore, in the VECM model, the error correction coefficient of these variables could be imposed restriction as $0 \mathrm{i}$. The VECM model is finally estimated in which the normalization is made on balance variable and error correction coefficients of the weak exogenous variables are set equal to 0 . The results of residual tests for the restricted VECM model indicate that this model does not show any evidence of autocorrelation and heteroskedasticity problems.

Table. 3. Johansen co-integration tests for levels of variables

\begin{tabular}{|c|c|c|c|c|}
\hline \multicolumn{5}{|c|}{ Trace test } \\
\hline $\mathbf{H}_{0}$ & $\mathbf{H}_{1}$ & $\begin{array}{l}\text { Trace } \\
\text { Statistic }\end{array}$ & $\begin{array}{l}0.05 \\
\text { Critical } \\
\text { Value } \\
\end{array}$ & Prob \\
\hline $\mathrm{r}=0$ & $\mathrm{r}=1$ & 206.892 & 159.530 & 0.000 \\
\hline $\mathrm{r} \leq 1$ & $\mathrm{r}=2$ & 135.646 & 125.615 & 0.010 \\
\hline $\mathrm{r} \leq 2$ & $\mathrm{r}=3$ & 95.548 & 95.754 & 0.052 \\
\hline $\mathrm{r} \leq 3$ & $\mathrm{r}=4$ & 60.971 & 69.819 & 0.2068 \\
\hline \multicolumn{5}{|c|}{ Max-eigenvalue test } \\
\hline $\mathbf{H}_{0}$ & $\mathbf{H}_{1}$ & $\begin{array}{l}\text { Max- } \\
\text { Eigen } \\
\text { Statistic }\end{array}$ & $\begin{array}{l}0.05 \\
\text { Critical } \\
\text { Value } \\
\end{array}$ & Prob \\
\hline $\mathrm{r}=0$ & $\mathrm{r}=1$ & 71.246 & 52.363 & 0.000 \\
\hline $\mathrm{r} \leq 1$ & $\mathrm{r}=2$ & 40.098 & 46.231 & 0.196 \\
\hline$r \leq 2$ & $\mathrm{r}=3$ & 34.576 & 40.078 & 0.183 \\
\hline $\mathrm{r} \leq 3$ & $\mathrm{r}=4$ & 21.566 & 33.877 & 0.641 \\
\hline
\end{tabular}

Notes: $r$ is the number of cointegration relationships. The cointegration tests are carried out with intercepts and linear deterministic trends in VARs. The critical values are based on MacKinnon et al [12]. 


\subsection{Discussions of empirical result}

The statistics $\chi$ statistic2 of LR test for the hypothesis that variables of LNNFA_GDP, LNM2_GDP, LNREL_Y2, LNREER and LNTF_GDP are weak exogenous are 5.718, p-value is 0.335

\subsubsection{Long-run determinants of trade balance}

Table 4 presents the normalised co-integrating vector and the associated adjustment coefficients and Table 5 presents more detailed restricted VECM estimation. It is clear that the negative sign and significance of the adjustment coefficients are appropriate for the normalization. This also implies that trade balance can successfully self-adjust any time it diverges from the long-run equilibrium after shocks coming from other endogenous variables. And the impacts of the explanatory variables on trade balance in the long run could be investigated through the normalised co-integrating relationship.

Table. 4. Estimated co-integrating vector

\begin{tabular}{|c|c|c|c|c|c|c|c|c|}
\hline \multicolumn{9}{|c|}{ Normalized co-integrating coefficients, $\beta$} \\
\hline $\mathrm{TB} \mathrm{l}=$ & $\begin{array}{l}-72.435 \mathrm{LNOPEN} \\
(7.989) \\
{[-9.067]^{* *+}}\end{array}$ & $\begin{array}{l}\text { - 10.328LNNFA_GDP } \\
(2.548) \\
{[-4.054]^{* * *}}\end{array}$ & $\begin{array}{l}+34.855 \text { LNM2_GDP } \\
(3.823) \\
{[9.117]^{* *}}\end{array}$ & $\begin{array}{l}-11.977 \text { LNREL_Y2 } \\
(8.794) \\
{[-1.362]}\end{array}$ & $\begin{array}{l}-8.955 \text { LNREER } \\
(8.330) \\
{[-1.075]} \\
\end{array}$ & $\begin{array}{l}\text {-11.783LNFDI_GDP } \\
(1.966) \\
{[-5.993]^{+*}}\end{array}$ & $\begin{array}{l}+10.217 \text { LNTF_GDP } \\
(5.387) \\
{[1.900]^{\circ}}\end{array}$ & +213.141 \\
\hline \multicolumn{9}{|c|}{ Adjustment coefficients, $a$} \\
\hline$\triangle \mathrm{TBl}$ & $\triangle \mathrm{LNOPEN}$ & $\triangle \mathrm{LNNFA} G \mathrm{GDP}$ & $\triangle \mathrm{LNM}$ 2_GDP $_{\text {G }}$ & ALNREL_Y2 & $\triangle$ LNREER & $\triangle$ LNFDI_GDP $_{\text {G }}$ & $\triangle$ LNTF_GDP & \\
\hline $\begin{array}{l}-0.534 \\
(0.257) \\
{[-2.080]}\end{array}$ & $\begin{array}{l}-0.008 \\
(0.002) \\
{[-4.011]^{* * *}}\end{array}$ & $\begin{array}{l}0.000 \\
(0.000) \\
{[N A]}\end{array}$ & $\begin{array}{l}0.000 \\
(0.000) \\
{[N A]}\end{array}$ & $\begin{array}{l}0.000 \\
(0.000) \\
{[N A]}\end{array}$ & $\begin{array}{l}0.000 \\
(0.000) \\
{[N A]}\end{array}$ & $\begin{array}{l}-0.037 \\
(0.010) \\
{[-3.539]^{+4+}}\end{array}$ & $\begin{array}{l}0.000 \\
(0.000) \\
\text { NA] }\end{array}$ & \\
\hline
\end{tabular}

Note: Standard errors are in parentheses. $\mathrm{t}$ statistics are in square brackets. ${ }^{*},{ }^{*}$ and $* * *$ : statistically significant at $10 \%, 5 \%$ and $1 \%$, respectively.

The coefficient of openness is negative and statistically significant at $1 \%$ level, implying that in the long run, the greater trade openness can cause trade balance to deteriorate. Thus, in Vietnam, although trade liberalization contributes to increasing exports through creating more opportunities to integrate into the global market, imports also increase significantly. This reflects the structure of the economy, which depends much on the technology and inputs for domestic production and exports, given an immature development of supporting industries. The initial level of NFA is found to have negative and statistically significant impact on trade balance in the long run. This relationship could be explained through the inter-temporal perspective, accordingly, one economy with a relatively high initial NFA stock could afford to run trade deficit for long period without the risk of insolvency. The financial depth variable is positively associated with trade balance at $1 \%$ significance level. This result could be attributed to the possibility that the financial depth is a measurement for the development of financial system, the more developed the financial system is, the more savings are encouraged, contributing to trade balance improvement. The estimation result also points out that the impact of relative income on trade balance in the long run is not statistically significant at any conventional significance level. This implies that the relationship between relative income and trade balance is not clear, which is in line with different theoretical perspectives. On one hand, according to the inter-temporal approach, a small and open economy usually accepts trade deficit in the developing period for capital accumulation.

During this period, high marginal product of capital attracts more capital flows into the economy, then increasing foreign debts. When the economy reaches a higher development stage, return on capital decreases, trade surplus will be gradually maintained in order to repay the accumulated foreign debts. On the other hand, according to the multiplier and absorption approaches, relatively higher income could lead to an increase in imports, then deteriorating trade balance. The variable of REER is found to have negative impact on trade balance in the long run but the effect is not statistically significant, implying the association between REER and trade balance is unclear. This could be explained by the possibility that the increase in REER, i.e. the VND is depreciated, could make exports more competitive. However, Vietnamese exports are mostly manufacturing and processing products. Given lack of efficient supporting industries, the increase in exportation could lead to the increase in imported raw materials and also in the production cost to firms. The positive effect of REER on the competitiveness of exports could be then eliminated. FDI is found to have negative and statistically significant effect on trade balance in the long run, which implies that 
the increase in FDI may deteriorate trade balance. Vietnam is an economy with low labor productivity, serious lack of skilled workforce, immature development of supporting industries and limited technology capacity. Therefore, foreign investors mostly focus on the manufacturing and processing sectors, putting Vietnam in a very low position in the global value chain. A rise in FDI could consequently increase in imports at a large scale. Moreover, FDI has not yet become an important source to help spreading technology diffusion and improving domestic productivity, thus the impacts of FDI on export capacity of domestic firms is really limited. Finally, the coefficient of LNTF_GDP has positive sign and statistical significance at $10 \%$ level, implying that more capital mobility level, i.e. removing more capital account controls, could contribute to trade balance improvement in Vietnam.

Table. 5. Estimated restricted VECM model

\begin{tabular}{|c|c|c|c|c|c|c|c|c|}
\hline & $\Delta \mathrm{TBl}_{\mathrm{t}}$ & $\triangle \mathrm{LNOPEN}_{\mathrm{t}}$ & $\Delta$ LNNFA_GDP ${ }_{t}$ & $\Delta \mathrm{LNM2}$-GDP $\mathrm{t}_{\mathrm{t}}$ & $\triangle L N R E L_{-}{ }^{2} 2_{t}$ & $\triangle$ LNREER $_{t}$ & $\Delta$ LNFDI_GDP ${ }_{t}$ & $\Delta \mathrm{LNTF}_{-} \mathrm{GDP}_{\mathrm{t}}$ \\
\hline \multirow[t]{2}{*}{ Ect $_{t-1}$} & -0.534 & -0.008 & 0.000 & 0.000 & 0.000 & 0.000 & -0.037 & 0.000 \\
\hline & {$[-2.080]^{* *}$} & {$[-4.010]^{* *}$} & {$[\mathrm{NA}]$} & [NA] & {$[\mathrm{NA}]$} & [NA] & {$[-3.538]^{* * *}$} & [NA] \\
\hline \multirow[t]{2}{*}{$\Delta \mathrm{TB} 1_{\mathrm{t}-1}$} & & & 0.002 & & 0.008 & & 0.029 & -0.009 \\
\hline & & & {$[1.808]^{*}$} & & {$[2.753]^{* * *}$} & & {$[3.091]^{* * *}$} & {$[-2.205]^{* *}$} \\
\hline \multirow[t]{2}{*}{$\Delta \mathrm{TB}_{\mathrm{t}-2}$} & 0.416 & -0.005 & 0.002 & & 0.005 & & 0.016 & \\
\hline & {$[2.274]^{* *}$} & {$[-1.919]^{*}$} & {$[1.657]^{*}$} & & {$[2.220]^{* *}$} & & {$[2.124]^{*}$} & \\
\hline \multirow{2}{*}{$\triangle \mathrm{LNOPEN}_{\mathrm{t}-1}$} & & & & -0.448 & 0.472 & & & -0.650 \\
\hline & & & & {$[-1.757]^{*}$} & {$[1.881]^{*}$} & & & {$[-1.941]^{*}$} \\
\hline \multirow[t]{2}{*}{$\triangle \mathrm{LNOPEN}_{\mathrm{t}-2}$} & 39.137 & -0.681 & & & 0.492 & -0.253 & 1.846 & \\
\hline & {$[2.098]^{* *}$} & {$[-2.664]^{* * *}$} & & & {$[1.998]^{*}$} & {$[-3.488]^{* * *}$} & {$[2.343]^{* *}$} & \\
\hline \multirow[t]{2}{*}{$\Delta$ LNNFA_GDP $P_{t-1}$} & & 0.7613 & 0.640 & 0.522 & & & & 0.704 \\
\hline & & {$[2.482]^{* *}$} & {$[4.710]^{* * *}$} & {$[1.741]^{*}$} & & & & {$[1.788]^{\circ}$} \\
\hline \multirow[t]{2}{*}{$\Delta$ LNNFA_GDP $P_{t-2}$} & & -0.546 & & -0.586 & 0.665 & & & -0.715 \\
\hline & & {$[-5.824]^{* *}$} & & {$[-6.394]^{* * *}$} & {$[7.375]^{* * *}$} & & & {$[-5.944]^{* * *}$} \\
\hline \multirow[t]{2}{*}{$\Delta \mathrm{LNM} 2{ }_{2} \mathrm{GDP}_{\mathrm{t}-1}$} & & & 0.3935 & & & & -2.071 & \\
\hline & & & {$[2.503]^{* *}$} & & & & {$[-1.894]^{*}$} & \\
\hline \multirow[t]{2}{*}{$\Delta \mathrm{LNM}_{2} \mathrm{GDP}_{\mathrm{t}-2}$} & -84.238 & 0.818 & -0.367 & & & 0.235 & & \\
\hline & {$[-3.055]^{* *}$} & {$[2.165]^{* *}$} & {$[-2.190]^{* *}$} & & & {$[2.197]^{* *}$} & & \\
\hline \multirow[t]{2}{*}{$\Delta$ LNREL_Y2 ${ }_{\mathrm{t}-1}$} & & 1.0508 & & 1.271 & -0.829 & & & 1.059 \\
\hline & & {$[3.020]^{* * *}$} & & {$[3.735]^{* *}$} & {$[-2.473]^{* *}$} & & & {$[2.372]^{* *}$} \\
\hline \multirow[t]{2}{*}{$\Delta$ LNREL_Y $2_{\mathrm{t}-2}$} & -63.883 & 1.3089 & 0.315 & 1.003 & -0.963 & & 2.791 & 0.909 \\
\hline & {$[-2.282]^{* *}$} & {$[3.413]^{* * *}$} & {$[1.856]^{*}$} & {$[2.675]^{* * *}$} & {$[-2.607]^{* * *}$} & & {$[2.361]^{* *}$} & {$[1.848]^{\circ}$} \\
\hline \multirow[t]{2}{*}{$\Delta$ LNREER $_{\mathrm{t}-1}$} & -67.650 & & -0.393 & 0.903 & & 0.254 & 3.605 & 0.998 \\
\hline & {$[-2.111]^{* *}$} & & {$[-2.020]^{* *}$} & {$[2.103]^{* *}$} & & {$[2.041]^{* *}$} & {$[2.664]^{* * *}$} & {$[1.772]^{\circ}$} \\
\hline \multicolumn{9}{|l|}{$\Delta$ LNREER $_{\mathrm{t}-2}$} \\
\hline \multirow[t]{2}{*}{$\Delta$ LNFDI_GDP $P_{t-1}$} & & & & & & & -0.448 & \\
\hline & & & & & & & {$[-2.804]^{* * *}$} & \\
\hline \multirow[t]{2}{*}{$\Delta$ LNFDI_GDP $_{\mathrm{t}-2}$} & & & & & & 0.0248 & & \\
\hline & & & & & & {$[2.110]^{* *}$} & & \\
\hline$\Delta \mathrm{LNTF}_{-} \mathrm{GDP}_{\mathrm{t}-1}$ & & & 0.271 & 0.114 & & & 0.965 & 0.392 \\
\hline
\end{tabular}




\begin{tabular}{|c|c|c|c|c|c|c|c|c|}
\hline & & & [ 3.498$]$ & & & & [ 1.786$]^{\circ}$ & {$[1.745]^{+}$} \\
\hline \multirow[t]{2}{*}{$\Delta$ LNTF_GDP ${ }_{\mathrm{t}-2}$} & & -0.444 & & -0.490 & 0.430 & & & -0.770 \\
\hline & & {$[-2.146]^{* *}$} & & {$[-2.417]^{* *}$} & {$[2.157]^{* *}$} & & & {$[-2.897]^{* * *}$} \\
\hline \multicolumn{9}{|l|}{$\mathrm{C}$} \\
\hline R-squared & 0.621 & 0.807 & 0.973 & 0.849 & 0.857 & 0.425 & 0.610 & 0.806 \\
\hline Adj. R-squared & 0.503 & 0.748 & 0.965 & 0.803 & 0.813 & 0.247 & 0.490 & 0.746 \\
\hline
\end{tabular}

Note: All the insignificant coefficients are not reported to keep the system simple. $t$ statistics are in square brackets. *, $* *$ and $* * *$ : statistically significant at $10 \%, 5 \%$ and $1 \%$, respectively.

\subsubsection{Short-run dynamics of trade balance}

The short-run dynamics of trade balance could be investigated through the impulse response functions, which are illustrated in Figure 1, and the variance decompositions, which are shown in Table 6.
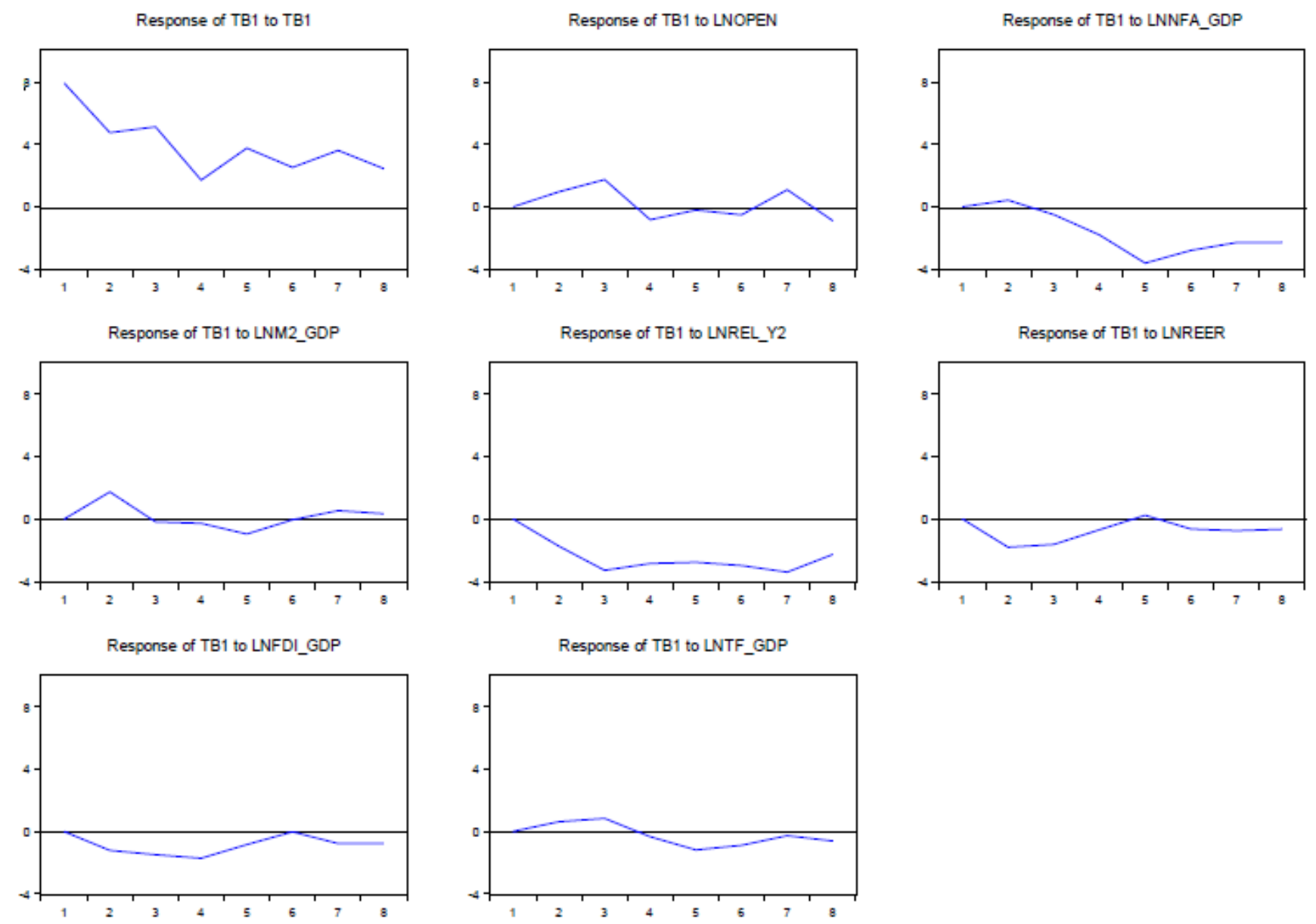

Figure. 1. Accumulated impulse responses of trade balance to one-unit standard deviation shocks

Figure 1 indicates that the response of trade balance to shocks to trade balance is very strong since the first quarter. The impact of shocks rapidly declines in the first four quarters before maintaining at a stable level. The variance decomposition results in Table 6 also show that shocks to trade balance can explain $100 \%$ of trade balance fluctuations in the first quarter and over $50 \%$ from the eighth quarter. 
Table. 6. Forecast error variance decompositions

\begin{tabular}{lcccccccc}
\hline $\begin{array}{c}\text { Horizon } \\
\text { (quarter) }\end{array}$ & TB1 & LNOPEN & LNNFA_GDP & LNM2_GDP & LNREL_Y2 & LNREER & LNFDI_GDP & LNTF_GDP \\
\hline 1 & 100.000 & 0.000 & 0.000 & 0.000 & 0.000 & 0.000 & 0.000 & 0.000 \\
2 & 87.436 & 0.933 & 0.171 & 3.112 & 3.081 & 3.337 & 1.523 & 0.407 \\
3 & 77.810 & 2.731 & 0.295 & 2.140 & 9.571 & 4.095 & 2.594 & 0.764 \\
4 & 70.709 & 2.854 & 2.286 & 1.941 & 13.436 & 3.911 & 4.118 & 0.744 \\
5 & 64.310 & 2.338 & 8.414 & 2.033 & 14.718 & 3.201 & 3.692 & 1.294 \\
6 & 60.108 & 2.210 & 11.009 & 1.812 & 17.045 & 3.025 & 3.290 & 1.502 \\
7 & 57.556 & 2.392 & 11.684 & 1.698 & 19.367 & 2.854 & 3.107 & 1.340 \\
8 & 55.832 & 2.522 & 12.797 & 1.628 & 19.922 & 2.812 & 3.102 & 1.384 \\
\hline
\end{tabular}

Positive shocks coming from trade openness start to improve trade balance in the second and third quarters. However, from the fourth quarter, the trade balance is deteriorated and only slightly improved in the seventh quarter. This is in line with the long-run negative relationship between openness and trade balance. However, the variance decomposition points out that shocks to trade openness only explain about $2 \%$ of trade balance variation. The NFA shocks have virtually very little effect on trade balance in the first two quarters, but quickly worsen trade balance since the third quarter and the next [22]. This finding supports the negative association between the initial NFA position and trade balance in the long run. According to Table 6, the NFA shocks explain only $2.3 \%$ of trade balance fluctuations in the fourth quarter, but nearly $13 \%$ in the eighth quarter. The financial depth shocks improve trade balance in the second quarter, worsen trade balance in the fourth and fifth quarter, and then improve again since the fifth quarter.

This is in accordance with the positive long run impact of the financial depth on trade balance. Nevertheless, Table 6 points out that the financial depth shocks explain negligibly the variation of trade balance in the short run. The shocks to relative income negatively affect trade balance in the second quarter, and the magnitude of impact remains stable since the third quarter, which implies that expenditure effects due to income increase is relatively strong in the short run [23]. The variance decompositions in Table 6 show that the importance of relative income in explaining trade balance fluctuation is relatively large compared to other explanatory variables. After one year, relative income shocks can explain $14.7 \%$ of trade balance variation and as much as $20 \%$ after 8 quarters. The REER shocks have negative impact on trade balance since the second quarter. Due to the initial shock, the trade balance starts to be be improved in the fifth quarter, and then deteriorated. This movement reflects the unclear relationship between REER and trade balance in the long run. Meanwhile, the FDI shocks make trade balance deteriorated since the second quarter and maintain the negative impact in the long run, which is in line with co-integrating relationship. The variance decompositions shown in Table 6 imply that the importance of REER and FDI in explaining trade balance variation is similarly small. Finally, the shocks to capital mobility could improve trade balance in the second and third quarter, before having negative impact since the fourth quarter. However, the maginitude of impact is not large. Table 6 also gives the similar result, in which, capital mobility shocks explain negligibly trade balance fluctuation (less than $1 \%$ after 1 year and $1.5 \%$ after 3 years).

\section{Conclusion and policy implications}

Based on the empirical results of the long-run determinants of trade balance and the short-run trade balance dynamics, we find that the greater trade openness potentially deteriorates trade balance. Vietnam should then prepare for possible challenges of a new phase of economic integration. The government should implement an efficient industrial development strategy to improve long run competitiveness of domestic firms, enhance the connectivity to the value chain and take advantage of the favorable conditions from different free trade areas. In addition, if Vietnam wants to increase the contribution of FDI to trade balance improvement, the economy has to guide foreign investors to the industries with high value-added and modern technology rather than ones that take advantage of cheap labor and natural resources. To do so, Vietnam needs to improve labor productivity and strongly develop supporting industries. The development of the financial system is found to contribute to improving trade balance. A healthy 
financial system could help increase saving investment ratio, which is an important condition for the sustainability of trade balance. Some recommendations for the soundness of the financial system include improving regulations on capital adequacy and asset quality, controling effectively the liquidity problems and enhancing non-performing loan solutions. Due to no close relationship between REER and trade balance, the VND devaluation may not improve trade balance. However, if the VND is overvalued for long following the fixed and USD-pegged exchange rate mechanism, the structure of production and exports as well as the supporting industries have no motivation to positively change in the long run. Therefore, the exhange rate managment should be more flexible within the limits allowed. In the medium term, when the macroeconomic conditions and the financial system are much improved along with more effective monitoring mechanism, the managed floating exchange rate mechanism should be a rational choice. Finally, the capital account control in Vietnam is now still relatively cautious. In the near future, based on the estimation results, policy makers should enhance the capital mobility to help improve trade balance.

\section{References}

[1] L. H. Hoang, “The Role of Exchange Rate in Supporting Trade Balance in Vietnam,” pp. 1-28, 2016.

[2] P. Thi and T. Trinh, "THE IMPACT OF EXCHANGE RATE FLUCTUATION ON TRADE BALANCE IN SHORT AND LONG RUN," 2012.

[3] M. U. T. Tran, "The factors affecting trade balance in Vietnam," 2012.

[4] W. Lee, "The Dynamics of the Trade Balance of Vietnam and Its Weak Currency Policy : A Bilateral Autoregressive Distributed Lag ( ARDL ) Analysis," vol. 8, no. 2, pp. 68-92, 2018.

[5] D. T. K. "Research on determinants of trade balance in V. a var approach. . P. 24: E. in H. and S. S. (2017). Dung, "Research on determinants of trade balance in Vietnam: a var approach," vol. 2, no. 2, 2017.

[6] D. T. X. Thom, "Exchange rate and trade balance in vietnam: A time series analysis," Asian Econ. Financ. Rev., vol. 8, no. 9, pp. 1158-1174, 2018, doi: 10.18488/journal.aefr.2018.89.1158.1174.

[7] T.-T. To, "An Inter-temporal Approach to Gauge Determinants of Trade Deficits in Vietnam during 1997-2012," Asian J. Agric. Extension, Econ. Sociol., vol. 8, no. 1, pp. 1-12, 2016, doi: 10.9734/ajaees/2016/20429.

[8] V. Van Trung and N. A. Thu, "Trade potential of climate smart goods of vietnam: An application of gravity model," Geogr. Pannonica, vol. 20, no. 1, pp. 8-18, 2016, doi: 10.5937/geopan1601008t.

[9] N. A. Prabowo, "With topological data analysis , predicting stock market crashes," IJIIS Int. J. Informatics Inf. Syst., vol. 4, no. 1, pp. 63-70, 2021.

[10]M. J. Shawa, “Analysis of the Determinants of Trade Balance: Case Study of Tanzania,” Int. J. Bus. Econ. Res., vol. 2, no. 6, p. 134, 2013, doi: 10.11648/j.ijber.20130206.13.

[11] T. P. N. Nguyen, P. L. Nguyen, and T. T. H. Dang, "Analyze The Determinants of Capital Structure for Vietnamese Real Estate Listed Companies,” Int. J. Econ. Financ. Issues, vol. 7, no. 4, pp. 270-282, 2017, [Online]. Available: http:www.econjournals.com.

[12] T. N. Tran, T. T. Nguyen, V. C. Nguyen, and T. T. H. Vu, "Energy consumption, economic growth and trade balance in East Asia: A panel data approach," Int. J. Energy Econ. Policy, vol. 10, no. 4, pp. 443-449, 2020, doi: 10.32479/ijeep.9401.

[13]N. H. Trang, “Limitations of Big Data Partitions Technology,” J. Appl. Data Sci., vol. 1, no. 1, pp. 11-19, 2020.

[14]M. G. Pradana and H. T. Ha, "Maximizing Strategy Improvement in Mall Customer Segmentation using K-means Clustering,” J. Appl. Data Sci., vol. 2, no. 1, pp. 19-25, 2021.

[15]T. H. Phan and J. Y. Jeong, "Vietnam trade balance and exchange rate: Evidence from panel data analysis.," J. Appl. Econ. Bus. Res., vol. 5, no. 4, pp. 220-232, 2015. 
[16]H. H. Ha and A. H. Nguyen, "Determinants of voluntary audit of small and medium sized enterprises: Evidence from Vietnam," J. Asian Financ. Econ. Bus., vol. 7, no. 5, pp. 41-50, 2020, doi: 10.13106/JAFEB.2020.VOL7.NO5.041.

[17]C. Van Dong and H. Q. Truong, "The determinants of creative goods exports: evidence from Vietnam," J. Cult. Econ., vol. 44, no. 2, pp. 281-308, 2020, doi: 10.1007/s10824-019-09359-y.

[18] V. T. ANH and V. H. DUC, "Trade Balance and Exchange Rate in Thailand \& the Implications for Vietnam: An Application using Instrumental Variable and the Heterogeneous Panel Cointegration Methods," J. Econ. Dev., vol. 23, no. 1, pp. 137-160, 2016, doi: 10.24311/jed/2016.23.1.04.

[19] L. Van Huy, F. Rowe, D. Truex, and M. Q. Huynh, “An empirical study of determinants of E-Commerce adoption in SMEs in Vietnam: An Economy in Transition,” J. Glob. Inf. Manag., vol. 20, no. 3, pp. 23-54, 2012, doi: 10.4018/jgim.2012070102.

[20]H. Vu and D. Nahm, "The determinants of profit efficiency of banks in Vietnam," J. Asia Pacific Econ., vol. 18, no. 4, pp. 615-631, 2013, doi: 10.1080/13547860.2013.803847.

[21]T. H. Tran, "Impacts of Exchange Rate on Vietnam-Japan Trade Balance: A Nonlinear Asymmetric Cointegration Approach Impacts of Exchange Rate on Vietnam-Japan Trade Balance: A Nonlinear Asymmetric Cointegration Approach," Mpra, no. 93286, 2019, [Online]. Available: https://mpra.ub.uni-muenchen.de/id/eprint/93286.

[22] N. T. Dao, V. N. Pham, and Q. H. Doan, "Analyzing the Determinants of Services Trade Flow between Vietnam and European Union: Gravity Model Approach," MPRA Pap., vol. 63982, no. 5, pp. 1-25, 2015, [Online]. Available: https://mpra.ub.uni-muenchen.de/63982/1/MPRA_paper_63982.pdf.

[23]T. A. Phan, "The Determinants of Inflation in Vietnam: VAR and SVAR Approaches," SSRN Electron. J., pp. 1-28, 2014, doi: 10.2139/ssrn.2437712. 